To Maega $\mid$ Jurnal Pengabdian Masyarakat

Agustus 2021, Vol.4, No.2, hal. 153-159

$\operatorname{ISSN}(P): 2622-6332 ; \operatorname{ISSN}(E): 2622-6340$

http://www.ojs.unanda.ac.id/index.php/tomaega

\title{
Penyuluhan Perilaku Hidup Bersih dan Sehat (PHBS) sebagai Upaya Preventif dalam Memutus Rantai Penyebaran Covid-19 pada kalangan Mahasiswa Baru Farmasi
}

\author{
Sendi Lia Yunita ${ }^{1}$, Rizka Novia Atmadani ${ }^{1 *}$, Ika Ratna Hidayati ${ }^{1}$, Aurora Onyx Aldila ${ }^{1}$, \\ Farras Divie Rizqi ${ }^{1}$ \\ ${ }^{1}$ Program Studi Farmasi, Fakultas Ilmu Kesehatan, Universitas Muhammadiyah Malang \\ *Correspondent Email : rizkanovia@umm.ac.id

\section{Article History:} \\ Received: 13-01-2021; Received in Revised: 21-02-2021; Accepted: 22-03-2021 \\ DOI: http://dx.doi.org/10.35914/tomaega
}

\begin{abstract}
Abstrak
Corona Virus Disease - 19 telah ditetapkan oleh WHO (World Health Organization) atau Badan Kesehatan Dunia sebagai Kedaruratan Kesehatan Masyarakat yang Meresahkan Dunia (KMMD). Angka kasus wabah virus menunjukkan bahwa paling tidak sampai saat ini, peningkatan sangat terlihat cukup meningkat signifikan dengan rata - rata 100 kasus per hari. Maka dari itu tujuan dari penyuluhan ini adalah guna mengedukasi para mahasiswa terkait Perilaku Hidup Bersih dan Sehat (PHBS) yang akan dilakukan pada mahasiswa Farmasi Universitas Muhammadiyah Malang secara daring. Metode yang digunakan adalah melalui google meet, dengan durasi penyulihan 60 menit. Dalam pelaksanaan penyuluhan dilakukan evaluasi awal (pretest) kepada peserta menggunakan media google form guna mengukur pengetahuan dasar peserta terhadap Covid-19. Kemudian peserta akan diberikan materi penyuluhan, selanjutnya pelaksana memberikan evaluasi akhir (posttest). Hasilnya, dari total 21 mahasiswa yang turut serta dalam penyuluhan kali ini, didapatkan nilai pretest dan postest yang berbeda yang menunjukkan adanya peningkatan pengetahuan mereka tentang bagaimana Perilaku Hidup Bersih dan Sehat (PHBS).
\end{abstract}

Kata Kunci: Penyuluhan, Covid-19, PHBS, Mahasiswa Farmasi

\begin{abstract}
Corona Virus Disease - 19 has been designated by WHO (World Health Organization) or the World Health Organization as a Public Health Emergency that Concerns the World. The number of cases of virus outbreaks shows that at least until now, the increase is seen to be quite significant, with an average of 100 cases per day. Therefore, the purpose of this counseling is to educate students regarding Clean and Healthy Behavior (PHBS) which will be conducted online for Pharmacy students from University of Muhammadiyah Malang. The method used is through google meet, with a total duration of 60 minutes. In the implementation of counseling, an initial evaluation (pretest) was carried out to participants using Google Form media to measure participants' basic knowledge of Covid-19. Then participants will be given counseling material, then the implementer will provide a final evaluation (posttest). As a result, from a total of 21 students who participated in this counseling, different pretest and posttest scores were obtained which indicated an increase in their knowledge of how to be clean and healthy living behavior (PHBS).
\end{abstract}

Keywords : Counseling, Covid-19, PHBS, Pharmacy student 


\section{Pendahuluan}

Corona Virus Disease - 19 atau yang lebih popular dengan istilah Covid-19 telah ditetapkan oleh WHO (World Health Organization) atau Badan Kesehatan Dunia sebagai Kedaruratan Kesehatan Masyarakat yang Meresahkan Dunia (KMMD) pada tanggal 30 Januari 2020 dan akhirnya ditetapkan sebagai Pandemi pada tanggal 11 Maret 2020 (Purnamasari \& Raharyani, 2020). Covid-19 telah dinyatakan sebagai pandemi oleh Kesehatan Dunia Organisasi (WHO) sebagai kasus yang dikonfirmasi mendekati 200.000 pasien dengan apa yang akan melebihi 8000 kematian di lebih dari 160 negara. Setelah penyebaran awal di Wuhan dan Cina, Italia terkena serangan pertama di Eropa dan dampaknya sangat besar.

Virus ini menyebar sangat cepat sehingga 2 minggu dari kasus pertama didiagnosis 1000 pasien dinyatakan positif. Satu minggu kemudian, jumlah kasus positif melebihi 4600 , mencapai lebih dari 30.000 pasien dan 2.500 kematian pada 18 Maret 2020. Negara lain mengikuti, misalnya, Spanyol mengumumkan keadaan darurat pada 14 Maret dan mengumumkan tindakan serupa yang akan diambil (Spinelli \& Pellino, 2020). Setelah itu, menurut (Syakurah \& Moudy, 2020) coronavirus merupakan keluarga besar virus yang ditularkan secara zoonosis (antara hewan dan manusia) dan dapat menyebabkan gejala ringan hingga berat. Pada Indonesia saat ini menjadi salah satu negara di dunia yang terpapar oleh virus Covid-19. Sejak pertama kali virus itu diumumkan langsung oleh Presiden Joko Widodo, angka kasus wabah virus menunjukkan bahwa paling tidak sampai saat ini, peningkatan sangat terlihat cukup meningkat signifikan dengan rata - rata 100 kasus per hari. Kurva angka kasus Covid-19 pun sama sekali belum menunjukkan kecenderungan menurun. Berbagai sumber, baik dari dalam maupun luar negeri, telah memprediksi angka kasus Covid-19 di Indonesia akan mencapai puluhan bahkan ratusan ribu (Ansori, 2020).

Dengan uji tes diagnosis untuk pasien Covid-19 serta keberadaan virus Covid-19 di Indonesia menyebabkan efek yang berakibat pada beberapa sektor di Indonesia khususnya sektor ekonomi Indonesia (Ahmad, 2018). Dengan kondisi Indonesia yang memiliki lebih dari 267,7 juta orang penduduk, pandemi ini sangat memberikan efek kepada masyarakat Indonesia. Dimana tercatat menurut Komite Penanganan Covid-19 Dan Pemulihan Ekonomi Nasional (KPCPEN) dan juga Satuan Tugas Penanganan Covid19 tercatat kasus 569.707 kasus yang terinfeksi oleh penyakit ini serta terdapat 470.449 pasien yang telah sembuh dan juga tercatat 17.589 kasus yang dinyatakan meninggal. Dengan kondisi tersebut banyak sekali masyarakat yang ketakutan bahwa pandemi ini akan merusak ekonomi dan juga sisi sosial mereka. Data yang didapat dari Badan Pusat Statistik (BPS) pada bulan Agustus 2019, tingkat pengangguran terbuka mencapai 7,05 juta orang atau 5,28\% dari jumlah angkatan kerja. Center of Reform on Economics (CORE) Indonesia memperkirakan jumlah pengangguran terbuka pada kuartal kedua 2020 akan bertambah 4,25 juta orang sehingga tingginya angka pengangguran dipastikan akan memengaruhi penurunan pertumbuhan ekonomi (Livana et al., 2020). Dibuktikan dengan hasil penelitian (Sihaloho, 2020) dimana didapat pada tanggal 2 Maret 2020, nilai 
tukar rupiah masih tidak lemah seperti sekarang. Pada tanggal 2 Maret 2020, nilai tukar 1 USD terhadap rupiah adalah sebesar Rp. 14,265.00, sedangkan per tanggal 9 April 2020 nilai tukar 1 USD terhadap rupiah adalah sebesar Rp. 15,880.004.

Keberadaan virus Covid-19 dapat dikatakan tanpa pandang bulu, dikarenakan virus ini dapat menginfeksi siapapun tanpa memedulikan kasta atau kelas sosial seseorang, suku, dan juga agama, namun masyarakat kelas bawah merupakan kelompok yang paling rentan dan juga beresiko. Hal ini dapat terjadi dikarenakan masyarakat kelas bawah lebih rentan karena tidak memiliki ketahanan sosial yang lebih baik, dan juga akan merasakan dampak terbesar ditambah jumlahnya yang dominan di negara - negara berkembang seperti Indonesia (Ansori, 2020). Maka dari itu, penting bagi kita untuk segera memutus rantai penyebaran Covid-19 sebagai cara untuk dapat mengembalikan kondisi seperti seharusnya. Adapun cara terbaik untuk melakukan upaya preventif pada penyakit ini adalah dengan memutus mata rantai penyebaran Covid-19 melalui isolasi, deteksi dini dan melakukan proteksi dasar yaitu dengan cara mengaktifkan kembali Perilaku Hidup Bersih dan Sehat (PHBS).

Berdasarkan uraian diatas maka penulis merencanakan pelaksanaan penyuluhan yang menitik beratkan pada Perilaku Hidup Bersih dan Sehar (PHBS) yang dilakukan pada mahasiswa Farmasi Universitas Muhammadiyah Malang secara daring atau dalam jaringan. Dimana fokus penyuluhan ialah untuk dapat memberikan informasi kepada masyarakat khususnya mahasiswa yang memiliki tingkat pengetahuan yang baik untuk selalu menjaga dan mempraktikkan Perilaku Hidup Bersih dan Sehat (PHBS) dimana berisikan untuk dapat selalu mencuci tangan, membersihkan badan setelah dari luar rumah, melakukan isolasi diri apabila dirasa tubuh tidak begitu bertenaga, dan selalu menggunakan masker serta membawa hand sanitizer dimanapun ia berada dengan tujuan dapat sebagai upaya kecil dalam melakukan preventif serta upaya untuk memutus rantai penyebaran COVID-19 di Indonesia.

\section{Metode}

Pelaksanaan penyuluhan perilaku hidup bersih dan sehat (PHBS) sebagai upaya preventif dalam memutus rantai penyebaran Covid-19 kepada mahasiswa Farmasi Universitas Muhammadiyah Malang Angkatan 2019 dilakukan secara daring (dalam jaringan) dalam konteks ini dalam jaringan merupakan jaringan online, yang dilaksanakan pada hari minggu tanggal 03 Jamuari 2021. Media penyuluhan dilakukan menggunakan google meet, dengan durasi penyulihan 60 menit. Dalam pelaksanaan penyuluhan dilakukan evaluasi awal (pretest) kepada peserta menggunakan media google form guna mengukur pengetahuan dasar peserta terhadap Covid-19. Kemudian peserta akan diberikan materi penyuluhan, selanjutnya pelaksana memberikan evaluasi akhir (posttest) kepada peserta menggunakan menggunakan instrumen kuesioner yang diujikan kepada responden dengan menggunakan media google form guna mengukur efektifitas penyuluhan dan bertambahnya pengetahuan peserta sebagai luaran kegiatan penyuluhan perilaku hidup bersih dan sehat (PHBS) sebagai upaya preventif dalam memutus rantai penyebaran Covid-19. Di dalam isntrumen tersebut penulis mengukur tentang nama (C)To Maega / Jurnal Pengabdian Masyarakat. This is an open access article under the CC BY-SA 4.0 license (https://creativecommons.org/licenses/by-sa/4.0/). 
virus, bagaimana penyebaran virus Covid-19, Berapa lama masa inkubasi virus, bagaimana mendeteksi adanya virus, bagaimana cara meningkatkan sistem imun tubuh, dan apa yang dapat dilakukan oleh diri kita supaya memutus mata rantai penularan virus tersebut.

\section{Hasil dan Pembahasan}

\section{a) Deskripsi Kegiatan Penyuluhan}

Kegiatan penyuluhan dilakukan dengan daring untuk mematuhi protokol kesehatan di tengah pandemi Covid-19 yang telah ditetapkan oleh pemerintah. Sebelum penyuluhan pihak pelaksana berkoordinasi dengan koordinator dari perwakilan mahasiswa baru Angkatan 2019 untuk mengkonfirmasi ketersediaan dan menyesuaikan jadwal. Adapun jadwal yang dilakukan pada saat penyuluhan adalah mulai dari persiapan penyelenggara, pretest peserta, pemberian materi penyuluhan, postest peserta, dokumentasi dan pembagian penghargaan seperti pada tabel 1 berikut ini.:

Tabel 1. Jadwal Kegiatan Penyuluhan

\begin{tabular}{ccc}
\hline No. & Nama & Waktu \\
\hline 1 & Persiapan Penyelenggara & $09.30-10.00$ WIB \\
\hline 2 & Pretest Peserta & $10.00-10.15$ WIB \\
\hline 3 & Penyuluhan & $10.15-11.15$ WIB \\
\hline 4 & Posttest Peserta & $11.15-11.30 \mathrm{WIB}$ \\
\hline 5 & Dokumentasi dan Pembagian Penghargaan & $11.30-11.40 \mathrm{WIB}$ \\
\hline
\end{tabular}

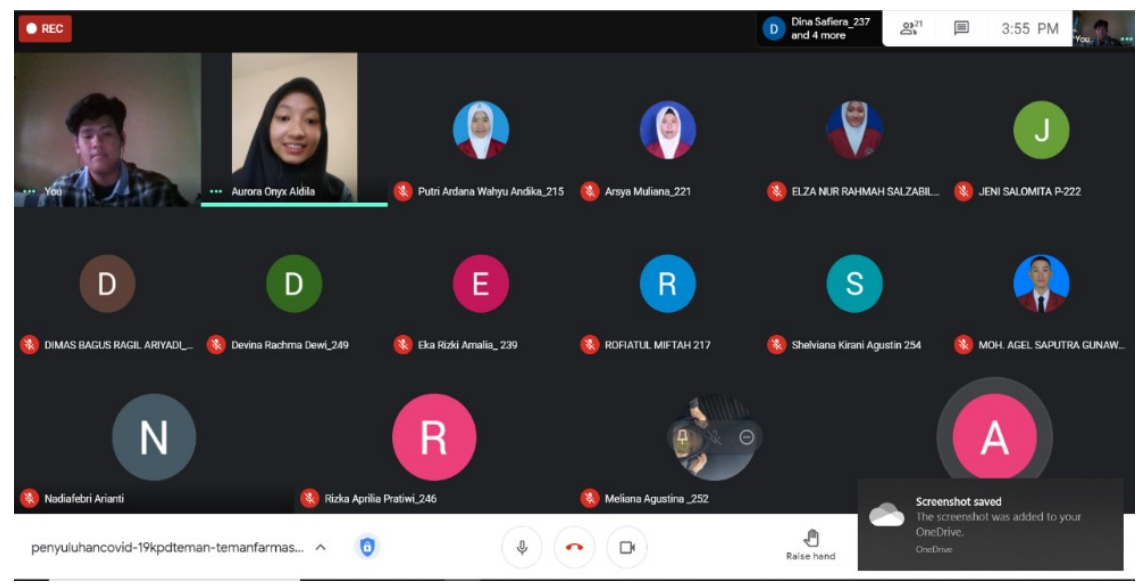

Gambar 1. Tampilan Kegiatan Penyuluhan melalui google meet

Pada hari dan tanggal yang telah disepakati penyelenggara menyiapkan link pertemuan google meet dan materi 30 menit sebelum waktu pelaksanaan. Pada saat yang bersamaan penyelenggara membagikan link untuk pretest peserta yang bertujuan untuk mengetahui pengetahuan awal dari masing-masing peserta. Selanjutnya penyuluhan dimulai setelah menunggu jumlah peserta lengkap dengan menampilkan materi power point sebagai pendukung, setelah pemaparan materi selesai dilanjutkan dengan diskusi 
bersama lalu dilanjutkan posttest, sedangkan untuk pembagian hadiah kepada peserta dikabarkan lebih lanjut melalui ketua kelas.
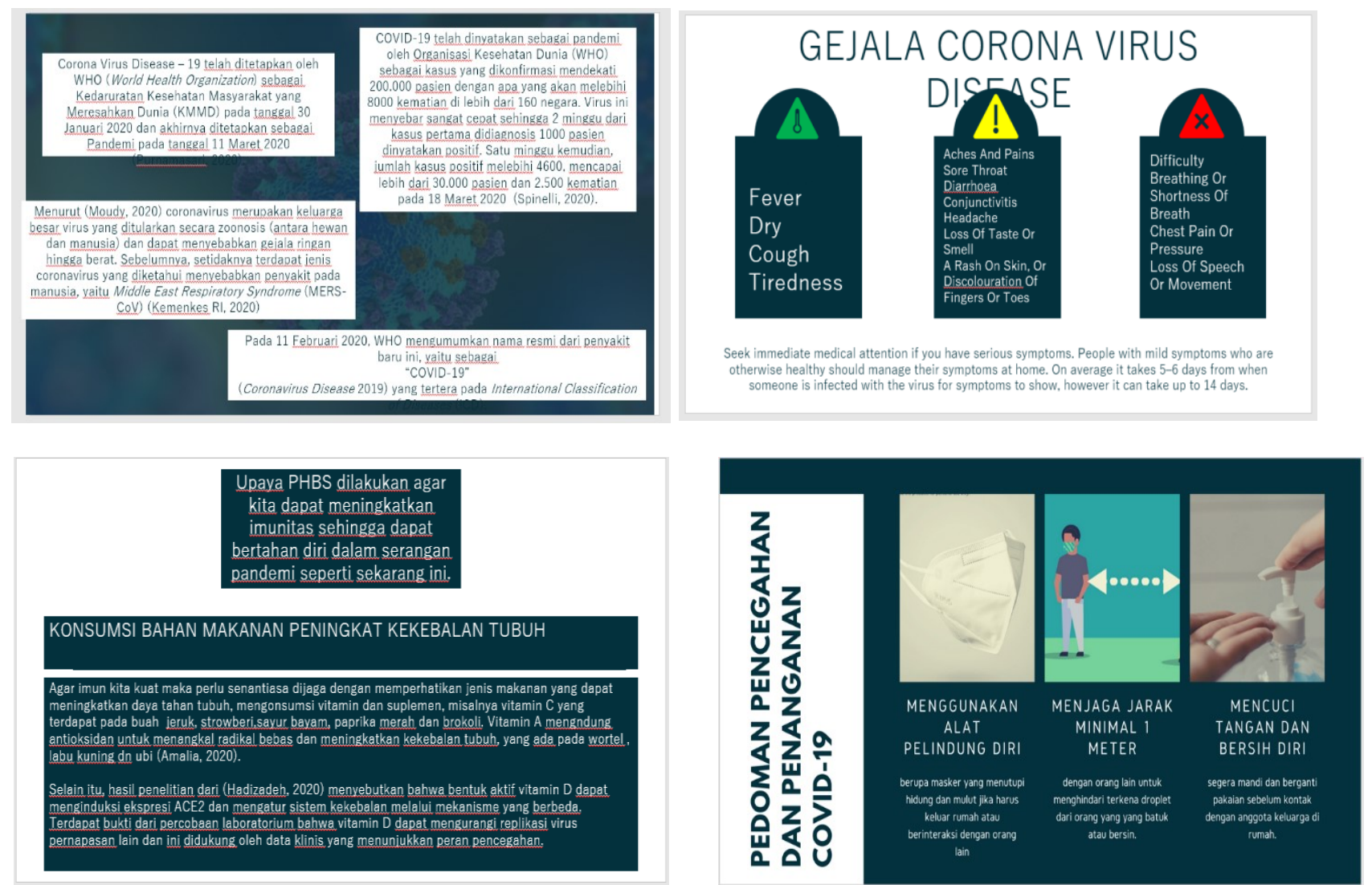

Gambar 2. Power point Materi Penyuluhan PHBS

Sesuai pada tema penyuluhan kali ini, materi yang diberikan berisi informasi terkait Virus Covid-19 yaitu terbagi menjadi beberapa materi diantaranya pengertian Covid 19, Bagaimana penyebaran, gejala, dan epidemiologinya, bagaimana dampak Covid-19 di Indonesia, bagaimana upaya preventif yang baik, dan terakhir adalah apa saja suplemen dan cara yang baik untuk melakukan preventif pada Covid-19. 


\section{b) Hasil Pretest dan Posttest Peserta}

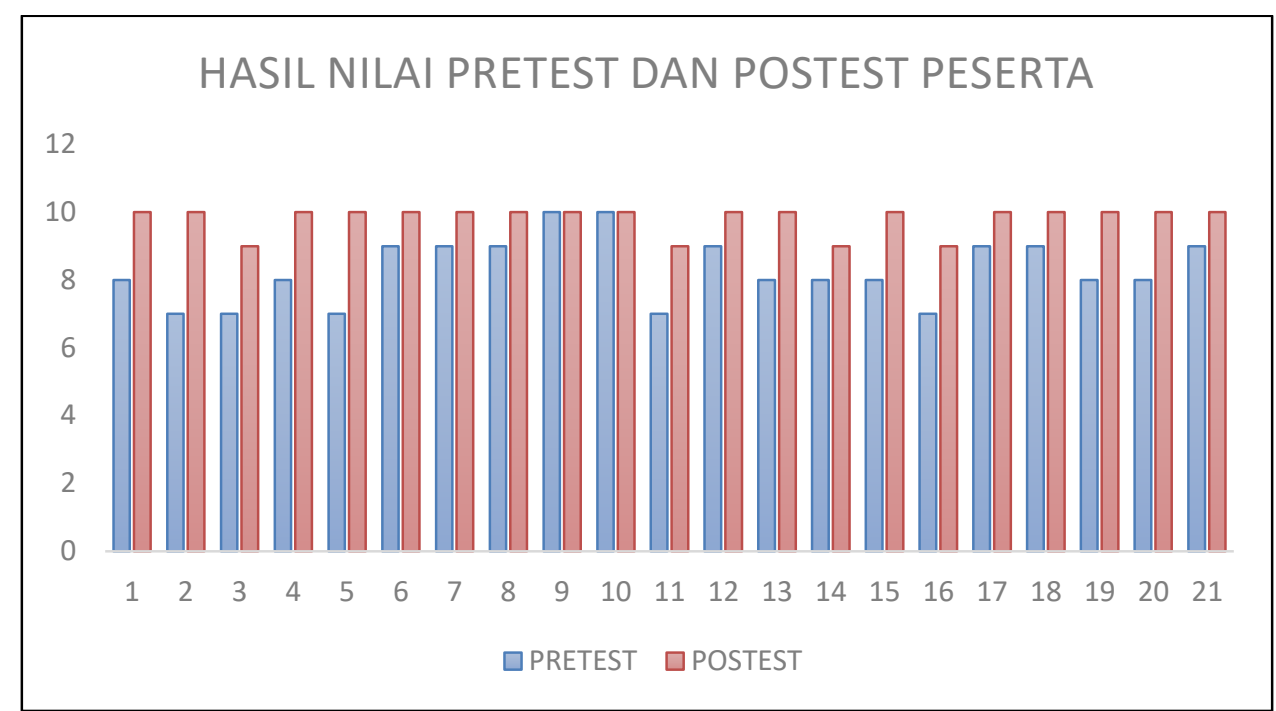

Gambar 3. Grafik Hasil Nilai Pretest dan Postest Peserta Penyuluhan

Berdasarkan hasil dari total 21 mahasiswa yang turut serta dalam penyuluhan kali ini, didapatkan nilai pretest dan postest yang berbeda. Dari hasil yang ada pada Gambar 3 menunjukkan adanya peningkatan pengetahuan mereka tentang bagaimana Perilaku Hidup Bersih dan Sehat (PHBS), dimana hampir pada semua peserta nilai pada saat setelah diberikan materi lebih tinggi dibandingkan saat sebelum diberikan materi penyuluhan. Hasil kegiatan ini juga didukung oleh hasil dari beberapa kegiatan pengabdian yang menggunakan metode pretest dan postest untuk mengukur tingkat pengetahuan sebelum dan sesudah adanya edukasi (Ariyanti et al., 2020; Atmadani \& Hidayati, 2020; Ristanti \& Masita, 2021) dimana terjadi peningkatan pada nilai postest para pesertanya setelah adanya edukasi materi penyuluhan. Hasil ini sesuai dengan teori yang dihasilkan oleh Muthia Farah (Muthia, 2016) pada penelitiannya yang menyebutkan bahwa terdapat perbedaan yang bermakna antara tingkat pengetahuan akhir dengan tingkat pengetahuan awal pada responden yang mendapat penyuluhan kesehatan dengan metode ceramah maupun dengan media audio visual film.

\section{c) Keunggulan Kegiatan}

Kegiatan penyuluhan ini memiliki keunggulan bagi masyarakat diantaranya yaitu dapat meningkatkan pengetahuan masyarakat tentang bagaimana Perilaku Hidup Bersih dan Sehat (PHBS), serta diharapkan peserta dalam penyuluhan tersebut dapat mnyebarluaskan informasi kepada kerabat dan masyarakat sekitar lainnya tentang Perilaku Hidup Bersih dan Sehat (PHBS) atau informasi terkait upaya - upaya dalam memutus rantai penyebaran Covid-19.

\section{d) Kendala Kegiatan Pengabdian Masyarakat}

Hambatan yang terjadi adalah sulitnya menghubungi peserta yaitu mahasiswa semester tiga Farmasi, dan beberapa yang sudah dicoba untuk mengkonfirmasi pada 
koordinator kelas kurang responsif sehingga hal ini cukup memberikan hambatan pada penyelenggara.

\section{Kesimpulan}

Pelaksanaan penyuluhan kali ini dengan fokus pada pemberian edukasi mengenai Perilaku Hidup Bersih dan Sehat (PHBS) kepada mahasiswa Farmasi semester tiga telah berhasil dilaksanakan dengan baik. Berdasarkan nilai pretest dan postest yang telah dilakukan, pemberian materi ini terbukti dapat meningkatkan pengetahuan mereka tentang bagaimana Perilaku Hidup Bersih dan Sehat (PHBS), dimana hampir pada semua peserta nilai pada saat setelah diberikan materi lebih tinggi dibandingkan saat sebelum diberikan materi penyuluhan. Adapun saran untuk pelaksanaan penyuluhan selanjutnya adalah, pertama memastikan dan membuat janji jauh-jauh hari dengan peserta penyuluhan dan membagikan brosur supaya lebih banyak peserta yang hadir, dan kedua, memastikan bahwa peserta dapat hadir secara daring mulai dari awal hingga akhir acara.

\section{Ucapan Terima kasih}

Terima kasih kepada seluruh mahasiswa Farmasi UMM semester tiga Angkatan 2019 yang berkenan turut serta dalam penyuluhan PHBS ini secara daring. Semoga materi yang disampaikan dapat bermanfaat dan dapat disampaikan kepada keluarga hingga masyarakat luas.

\section{Daftar Pustaka}

Ahmad, Z. (2018). Damayanti. Skin Aging: Pathophysiology and Clinical Managing. Berkala Ilmu Kesehatan Kulit Dan Kelamin, 30(3), 208-215.

Ansori, M. H. (2020). Wabah COVID-19 dan Kelas Sosial di Indonesia. habibiecenter.or.id

Ariyanti, R., Preharsini, I. A., \& Sipolio, B. W. (2020). Edukasi Kesehatan Dalam Upaya Pencegahan dan Pengendalian Penyakit Hipertensi Pada Lansia. To Maega: Jurnal Pengabdian Masyarakat, 3(2), 74-82.

Atmadani, R. N., \& Hidayati, I. R. (2020). Pelatihan Apoteker Cilik dan DaGuSiBu bagi Siswa SDN Losari di Singosari, Kabupaten Malang. Jurnal Pengabdian UNDIKMA: Jurnal Hasil Pengabdian Dan Pemberdayaan Kepada Masyarakat, 1(2), 77-81.

Livana, P. H., Suwoso, R. H., Febrianto, T., Kushindarto, D., \& Aziz, F. (2020). Dampak pandemi COVID-19 bagi perekonomian masyarakat desa. Indonesian Journal of Nursing and Health Sciences, 1(1), 37-48.

Muthia, F. (2016). Perbedaan Efektifitas Penyuluhan Kesehatan menggunakan Metode Ceramah dan Media Audiovisual (Film) terhadap Pengetahuan Santri Madrasah Aliyah Pesantren Khulafaur Rasyidin tentang TB Paru Tahun 2015. Jurnal Mahasiswa PSPD FK Universitas Tanjungpura, 2(4).

Purnamasari, I., \& Raharyani, A. E. (2020). Tingkat pengetahuan dan perilaku masyarakat Kabupaten Wonosobo tentang Covid-19. Jurnal Ilmiah Kesehatan, $10(1), 33-42$.

(C)To Maega / Jurnal Pengabdian Masyarakat. This is an open access article under the CC BY-SA 4.0 license (https://creativecommons.org/licenses/by-sa/4.0/). 
Ristanti, A. D., \& Masita, E. D. (2021). Peran Kader dalam Mendorong Pemberian Asi Di Masa Pandemi Covid-19. To Maega: Jurnal Pengabdian Masyarakat, 4(1), 4754.

Sihaloho, E. D. (2020). Dampak Covid-19 Terhadap Perekonomian Indonesia. researchgate.net

Spinelli, A., \& Pellino, G. (2020). COVID-19 pandemic: perspectives on an unfolding crisis. The British Journal of Surgery.

Syakurah, R. A., \& Moudy, J. (2020). Pengetahuan terkait usaha pencegahan Coronavirus Disease (COVID-19) di Indonesia. HIGEIA (Journal of Public Health Research and Development), 4(3), 333-346. 